\title{
From Entrepreneurial Aspirations to Founding a Business: The Case of Russian Students
}

\author{
Karina Bogatyreva ${ }^{a}$ \\ Assistant Professor, k.bogatyreva@gsom.pu.ru \\ Galina Shirokova ${ }^{\text {a;b }}$ \\ Professor; and Chief Researcher at Chair of Management, shirokova@gsom.pu.ru \\ ${ }^{\text {a }}$ Graduate School of Management, Saint-Petersburg University, 3 Volkhovsky pereulok, St. Petersburg 199004, \\ Russian Federation. \\ b School of Economics and Management, Far Eastern Federal University, 8, Sukhanova str., Vladivostok 690091, \\ Russian Federation.
}

\begin{abstract}
$\mathrm{T}$

The formulation of entrepreneurial aspirations represents one of the key stages of the entrepreneurial process. In practice, however, not every declared intention is eventually translated into a viable enterprise, creating the phenomenon of the intention-action gap. This study is based upon the key principles of embeddedness perspective and the theory of planned behavior, considering a variety of factors that are able to increase or diminish the probability of an actual shift from entrepreneurial intentions to concrete start-up activities. These factors include the presence of a family business, support from

a university entrepreneurial environment, and the level of development of regional entrepreneurial institutions. An analysis of data on 4,484 students from 32 Russian universities gathered over the course of the international project, the Global University Entrepreneurial Spirit Students' Survey (GUESSS), in 2013-2014 revealed a negative correlation between a family business and the probability of a potential entrepreneur's shift from entrepreneurial aspirations to the actual creation of a startup enterprise. The development of regional entrepreneurial institutions, on the other hand, exhibits a positive link.
\end{abstract}

\section{Keywords:}

entrepreneurial intention;

intention-action gap;

student entrepreneurship;

small and medium business in Russia;

GUESSS.

Citation: Bogatyreva K., Shirokova G. (2017) From

Entrepreneurial Aspirations to Founding a Business:

The Case of Russian Students. Foresight and STI

Governance, vol. 11, no 3, pp. 25-36. DOI: 10.17323/2500-

2597.2017.3.25.36 
$\mathrm{T}$ he positions small and medium enterprises (SME) currently hold in the Russian economy can be described as weak, which significantly hinders the country's overall development. SME's share of the total turnover of goods and services is $25.4 \%$, which is quite low compared with developed nations [Romanovskaya, 2015]. In 2015, the Russian government included support for small and medium enterprises in its package of anti-crisis measures [World Bank, 2015]. A specific form of such support is promoting careers in entrepreneurship among young Russians and creating conditions that would encourage them to set up and run their own companies [Karpunina et al., 2014]. Students are a particularly promising group in this respect [Shchegolev, Nikolaev, 2014]. Student entrepreneurship could promote young people's integration into the business environment, and step up economic activity of the country's able-bodied population [Khairetdinova, 2014].

Of 4,484 students of 32 Russian universities surveyed in 2013-2014 as part of the international project Global University Entrepreneurial Spirit Students' Survey (GUESSS) ${ }^{1}$, about 53\% have stated their intentions to start their own business within five years following graduation [Shirokova et al., 2015a]. However, entrepreneurial aspirations as such do not always translate into the actual implementation of a business idea - not by far. The phenomenon of the intention-action gap, i.e., failing to implement previous intentions, commands significant interest from psychologists (see e.g. [Ajzen, Czasch, Flood, 2009; Armitage, Conner, 2001; Orbell, Sheeran, 1998; Sheeran, 2002; Sniehotta et al., 2005]). However, very few relevant studies were conducted by researchers specializing in entrepreneurship (see e.g. [Kautonen et al., 2013; Shirokova et al., 2015b; van Gelderen et al., 2015]). No such studies were found for Russia at all. Identifying factors which affect the probability (its increase or decrease) of moving on from entrepreneurial intentions to actually establishing a company seems to be a particularly relevant objective at this stage [Liñán, Fayolle, 2015].

Entrepreneurial intentions and their implementation largely depend on nascent entrepreneurs' personal characteristics [Liñán, Fayolle, 2015]. The external environment also plays a role, since it affects individuals behavior including their involvement in entrepreneurship [Rauch, 2014]. This hypothesis is based on the "embeddedness perspective" concept which links people's actions to the system of social relations and the context in which they are immersed [Welter, 2013; Granovetter, 1985; Welter, 2011]. The goal of our paper is to assess the impact of factors affecting, at various levels, the context of Russian university students' moving on from entrepreneurial intentions to actually taking action on starting a new business. The originality of the study lies in its further elaboration of the planned behavior theory [Ajzen, 1991] by identifying the reasons of such a transition's success. The study also considers the applicability of the embeddedness perspective for analyzing the role of various parameters of the environment in which entrepreneurship takes place. Finally, the traditional scope for applying an institutional approach to studying entrepreneurship was extended by considering the role of the regional institutional environment in the entrepreneurial intention-action transition.

The first section of the paper presents the theoretical basis of the study and formulates the hypotheses. Next comes a description of the applied methodology. The third section describes the results of the data analysis, and the fourth contains a discussion about them. The final section formulates our main conclusions, points out the limitations of the study, and outlines areas for future research in this field.

\section{Theoretical basis and hypotheses of the study}

According to the theory of planned behavior [Ajzen, 1991], targeted action by individuals is preceded by the emergence of their intentions, which in turn are affected by the following factors:

- Personal attitude toward the relevant activities;

- Perceived behavioral control based on the individual's perception of how easy or difficult implementing their plans is going to be;

- Subjective norms defined by public opinion, which can either encourage one to or discourage one an individual from implementing said plans.

Intentions serve as an intermediate link between the above factors, a bridge to implementing action and achieving the desired objectives [Armitage, Conner, 2001].

The mechanism of intention formation remained the focus of attention of researchers specializing in entrepreneurship for a long time (see e.g. [Bird, 1988; Heuer, Liñán, 2013; Krueger, 2009; Liñán, RodriguezCohard, 2015; Shapero, Sokol, 1982; Schlaegel, Koenig, 2014; Shook, Bratianu, 2003]). The correlation between entrepreneurial intentions and the actual action they take empirically confirms the provisions of the theory of planned behavior [Kautonen et al., 2013; 2015; Liñán, Fayolle, 2015; van Gelderen et al., 2015]. For student entrepreneurs, this correlation is just as valid as it is for older age groups [Shirokova et al., 2015a]. Being in a career choice situation forces students who intend to become entrepreneurs to

\footnotetext{
For more details about the project see: http://www.guesssurvey.org/, last accessed on 26.08.2016.
} 
start doing something about it while they still continue their studies, to lay the groundwork for the future growth of their companies.

At the same time, the correlation between intention and action is rather weak. Previous studies show that the presence of the former explains no more than $30 \%$ of the resulting attribute's variation - i.e. the implementation of actual action [Armitage, Conner, 2001; Sheeran, 2002]. These results indicate the situational nature of the intention-action transformation, and the presence of factors promoting or inhibiting this process. According to the embeddedness theory [Granovetter, 1985], the system of social relations and the context in which individuals find themselves significantly affect their behavior. Regarding entrepreneurship, it means that the probability of moving on from intention to action on starting a business may depend on specific characteristics of the individual's environment. In our study, we propose and put forward a hypothesis that, for student entrepreneurs, this transition is embedded in the context of the family they come from, the university environment they are immersed in, and the region where they live and study.

\section{Coming from a business-owning family}

Coming from a business-owning family may largely pre-determine students' career choices, prompting them to follow their parents' career path and start their own business [Laspita et al., 2012]. Entrepreneurial parents may become role models for those students [Chlosta et al., 2012]. Also, people who come from a business-owning family tend to possess a higher quality of human capital due to the experience, knowledge, and skills necessary for running a business picked up from their parents, among other things, by participating in the management of the family firm [Lentz, Laband, 1990; Mueller, 2006]. Such students often feel more confident moving from entrepreneurial aspirations to action, which ultimately increases the likelihood of their creating a new company [Shirokova et al., 2015b].

Besides developing human capital, business owners may help their children to find and obtain the necessary resources for realizing their entrepreneurial intentions. Specifically, business owning parents serve as a source of financial support for their children [Dunn, Holtz-Eakin, 2000] and provide them with access to their social capital, i.e., the network of partners, suppliers, investors, and customers [Laspita et al., 2012]. The aforementioned early-stage advantages of people coming from business-owning families over other nascent entrepreneurs help them successfully complete the transition from intention to starting a business. No less important is the emotional support from the older generation: approval or encouragement is another important incentive to actually become an entrepreneur [Zanakis et al., 2012]. Russian entrepreneurs note the special role family support plays at the stage of business creation and initial development [Djankov et al., 2006; McCarthy et al., 2010]. As was already established, believing one's knowledge and skills to be sufficient to run a business and possessing the required practical experience serve as major prerequisites for the emergence of relevant intentions in Russia [Aleksandrova, Verkhovskaya, 2015]. All these factors can be presumed also to be significant for people coming from a business-owning family, which may lead to not only the formation of corresponding intentions by Russian students, but their taking direct action to implement them. The above arguments allow one to put forward the following hypothesis:

H1: The positive relationship between entrepreneurial intentions and start-up activities will be stronger for Russian students with a family entrepreneurial background.

\section{University entrepreneurial environment}

Apart from the family environment, the creation of one's own businesses by students is also affected by the university context [Shirokova et al., 2015b]. Potential student entrepreneurs spend most of their time at their place of study, so the academic environment significantly influences their disposition towards particular activities. Specifically, students' entrepreneurial intentions and their subsequent transformation into action may be affected by the university's initiatives aimed at promoting student entrepreneurship [Bae et al., 2014; Shirokova et al., 2015; Zhang et al., 2014].

Such initiatives include certain courses, e.g., entrepreneurship courses and seminars designed to give students the basic knowledge and skills required for running a business [Shirokova et al., 2014; Klofsten, 2000]. Educational initiatives are aimed at improving the quality of the crucial resource - human capital, to compensate for students' lack of experience as early-stage entrepreneurs [Zhao et al., 2005]. University-based business incubators and accelerators, whose residents receive the opportunity to quickly turn their ideas into actual start-ups, find investors, and seek out expert support, also play an important role in transforming entrepreneurial aspirations into action [Hughes et al., 2007]. The university may turn into a source of social capital for young entrepreneurs, through mentoring programs, seminars and training events with the participation of experienced businessmen, designed not only to provide useful knowledge and skills, but also to expand the students' network of business contacts [Nielsen, Lassen, 
2012; Davidsson, Honig, 2003; De Clercq, Arenius, 2006; Morales-Gualdron, Roig, 2005; Sequeira et al., 2007]. Finally, universities can provide access to financial capital through special funding programs for student startups [Parker, Belghitar, 2006].

In present-day Russia, the need to promote the entrepreneurial aspect of universities' activities is universally accepted [Shchegolev, Nikolaev, 2014]. Many universities run successful business incubators which help nascent entrepreneurs at the project launch stage. In particular, such universities include National Research University Higher School of Economics, Lomonosov Moscow State University, Financial University under the Government of the Russian Federation, St. Petersburg National Research University of Information Technologies, Mechanics and Optics, and others. The requirements for graduates are also changing: along with basic and specialized disciplines, a special effort is being made to promote specific personality traits such as initiative, leadership, enterprise, and the ability to generate new ideas and realize them [Zakharova, 2013; Reznik, Ponomarenko, 2010]. Taken together, these traits can significantly affect the emergence of entrepreneurial intentions and their subsequent implementation.

Today's educational programs and extracurricular activities increasingly often include business case studies, computerized business simulations, business plan development, workshops and master classes led by expert entrepreneurs, and targeted educational modules on entrepreneurship [Konyukhova, 2014; Shchegolev, Nikolaev, 2014; Shcherbakova, 2012]. Students participate in business plan competitions, which allows them not only to test their ideas and receive feedback from experts and experienced entrepreneurs but also, if they win, secure financial support for further development. In particular, such annual events include the student business plan competition held by the Graduate School of Management of St. Petersburg University, or the "My First Business" project by National University of Science and Technology MISiS. All of the above can be summarized in the following hypothesis:

H2: The positive relationship between entrepreneurial intentions and start-up activities will be stronger for Russian students coming from universities with a favorable entrepreneurial environment.

\section{Regional institutional environment}

Along with the family and university contexts, the emergence of entrepreneurial aspirations, and the likelihood of taking practical steps toward realizing them can also be affected by the external institutional conditions. The latter are defined by the institutions' specific features, which either promote or hinder the development of entrepreneurship in a region. This factor is particularly relevant in Russia, which is a country with significant disparities in many regions' entrepreneurial infrastructure, which directly affect small business development on a national scale [Saidullaev, 2015].

The institutional approach to studying entrepreneurship presumes that institutions set conditions under which entrepreneurs operate and make decisions on starting and running their businesses [Bruton et al., 2010; Peng, 2003]. These conditions may affect people's individual perception of their prospects for starting a business, and their willingness to move forward and take action to implement their entrepreneurial intentions [Kibler, 2013].

Entrepreneurial behavior is embedded into the institutional context and affected by a number of encouraging or discouraging factors [Welter, 2013; Welter, 2011; Welter, Smallbone, 2011] such as regulatory initiatives of the regional authorities [Stenholm et al., 2013]. Initiatives of this kind include regional small business and entrepreneurship promotion programs whose large-scale implementation increases the probability of nascent entrepreneurs' moving from intention to action and therefore investing their time, resources and efforts in setting up a company. However, low participation in such programs has been observed in most Russian regions and combined with other factors affecting regional development may have a more powerful negative impact upon this process. Other factors in this case include the state of the legal environment, administrative norms and the level of their enforcement in the region, and, finally, the level of corruption.

As was demonstrated in a recent study [Costa, Mainardes, 2016], the perceived level of corruption negatively affects the emergence of entrepreneurial intentions. It probably has the same effect on the transition from intentions to action. This is particularly critical for Russia, which holds $119^{\text {th }}$ place out of 167 in the perceived corruption ranking [Transparency International, 2015]. According to the European Bank for Reconstruction and Development (EBRD), in a number of Russian regions the high level of corruption is perceived as one of the largest barriers hindering business development [EBRD, 2012]. Various aspects of regional socioeconomic development also seem to be quite important, such as access to financial resources and human capital, i.e., the availability of personnel with particular qualifications and specializations; the size of market entry barriers created by factors such as the level and severity of competition and the presence of large firms in the region; effective demand; the availability of transport; access to technology and equipment; S\&T potential; information environment; resource self-sufficiency; the level of development of innovative territorial clusters, regional "business catalysts", etc. [Kutsenko, 2015; Makarov, Ugnich, 2015; Pavlov, 2008; Fritsch, Storey, 2014]. The above parameters significantly 
vary in different Russian regions [EBRD, 2012], as does their effect on the emergence of entrepreneurial intentions and the transition to action aimed at starting one's own business.

Keeping in mind the above arguments, the following hypothesis can be formulated:

H3: The positive relationship between entrepreneurial intentions and start-up activities will be stronger for Russian students coming from regions with a favorable institutional environment with respect to entrepreneurship.

A generalized theoretical model of the study is presented in Figure 1.

\section{Methodology of the study \\ Description of the sample}

The international GUESSS project (data collected in its framework provided the empirical basis of our study) was launched in 2003 by the Swiss Research Institute of Small Business and Entrepreneurship of the University of St. Gallen (KMU-HSG). Its objective was to study students' entrepreneurial aspirations taking into account such factors as family support, the university environment, and the socio-cultural context. In the scope of the GUESSS project, data is collected every two years with international coverage of students specializing in different fields of study. In 2013-2014, 109,026 students were surveyed at 759 universities in 34 countries. Russia has participated in the project since 2011. The national operator of the project is the Graduate School of Management of St. Petersburg University, which is responsible for recruiting Russian universities and the translation and distribution of questionnaires among the participants. Between the start of October and the end of December 2013, 4,578 Russian students were surveyed at 32 Russian universities ${ }^{2}$.

For the purposes of this study, students who came to Russia on exchange programs and those studying as part of continuing professional education programs were excluded from the general sample. The final sample comprised 4,484 students from 19 Russian regions.

\section{Measuring variables}

Dependent variable. Since our study is focused on the transition from entrepreneurial aspirations to taking action on starting one's own business, a binary variable was chosen as the resulting characteristic of the model. It takes the value of 0 if the student did not do anything to establish a company, and 1 if even a single practical step was actually taken. The list of such steps based on the international projects "Panel Study of Entrepreneurial Dynamics" (PSED) and "Global Entrepreneurship Monitor" (GEM) included the following: "Discussed product or business idea with potential customers", "Collected information about markets or competitors", "Has written up a business plan", "Launched product/service development", "Started marketing or promotion campaigns", "Purchased materials, equipment or machinery for the business", "Attempted to obtain external funding", "Applied for a patent, copyright or trademark", "Registered the company", and "Sold the product or service".

Independent variable. Students' entrepreneurial intentions were measured using the scale presented in [Liñán, Chen, 2009]. The respondents were asked to assess the following statements on a scale of 1

Figure 1. Theoretical model of the study

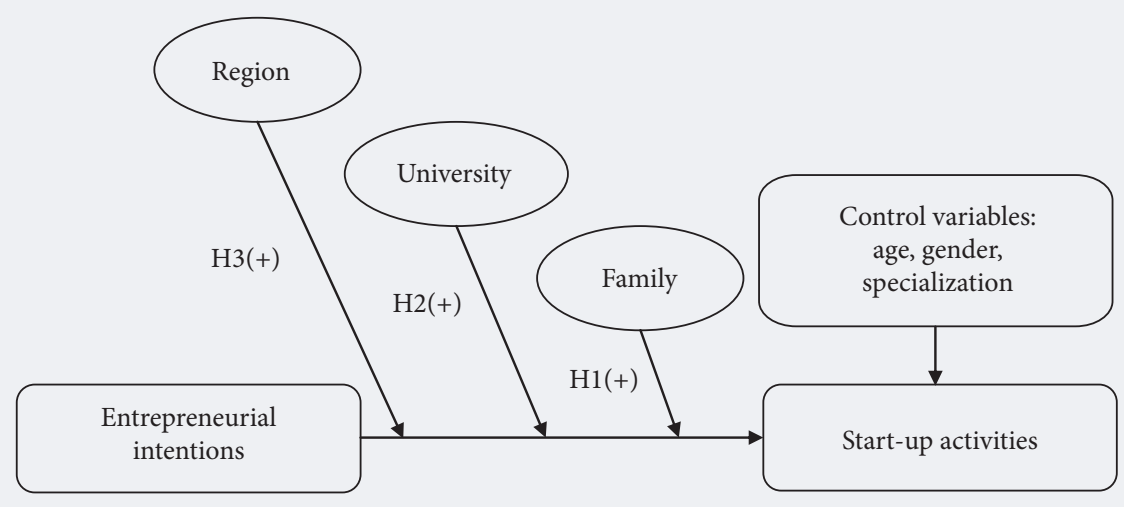

Source: compiled by the authors.

\footnotetext{
2 For more about the implementation of the GUESSS project in Russia in 2013-2014 see: [Shirokova et al., 2015b].
} 
(totally disagree) to 7 (completely agree) "I am ready to do anything to become an entrepreneur", "My professional goal is to become an entrepreneur", "I will make every effort to start and run my own firm", "I am determined to create a firm in the future", "I have very seriously thought of starting a firm", and "I have serious intentions of starting a firm someday". On the basis of the answers, the average strength of each student's entrepreneurial aspirations was calculated. The missing values were replaced with the average ones for the university, since the number of omissions did not exceed $7 \%$ of the total sample. The distribution of missing values by basic demographic characteristics (gender, age, profile of studies, family status) on average matched the general sample's trends, without any obvious outliers.

Moderators. For the purposes of this study, the following moderators of the relationship between students' intentions and their actual involvement in business activities were used: coming from a business-owning family; the university environment; and the level of development of the regional institutions responsible for promoting entrepreneurship.

Family entrepreneurial background. This variable takes the value of 1 if at least one of the student's parents is an entrepreneur, and 0 if that is not the case.

University entrepreneurial environment was assessed by students using a scale of 1 (totally disagree) to 7 (completely agree) to evaluate the following statements: "The atmosphere at my university inspired me to develop ideas for a new business", "There is a favorable climate for becoming an entrepreneur at my university", "At my university, students are encouraged to engage in entrepreneurial activities" [Franke, Lüthje, 2004; Geissler, 2013]. Missing values were substituted with averages for the university.

The level of development of regional institutions was operationalized using data collected by the analytical center of the Russian Small Business and Entrepreneurship Support Bank (MSP Bank, Inc.) in 20122013 through a survey entitled "Small and Medium Business Conditions Index" [MSP Bank, 2014]. The objective of the project was to assess business conditions in Russian regions on the basis of Rosstat data and the results of studies on the Russian entrepreneurial environment. The following indicators were used:

1) Production factors: access to necessary resources such as financial and human capital, and regional entrepreneurship infrastructure;

2) Demand and competition: market entry barriers, effective demand;

3) Regulatory impact: support of entrepreneurship provided by the regional authorities;

4) Macroeconomic risks: inflation, regional budget balance, the region's revenues/expenditures ratio, the share of expenditures in gross regional product;

5) Risks related to crime, excessive administrative barriers, and corruption.

The MSP Bank's rating ranked Russian regions by each of the above groups of factors depending on the "grade" they received (good, satisfactory, or poor). We converted these qualitative indicators into quantitative ones by assigning the following values to the assessments of the factor groups: $1=$ poor, 2 = satisfactory, and 3 = good. Next, the level of development of the institutions potentially capable of promoting or hindering entrepreneurship was calculated for each region. The list of regions, the number of the respondents covered by the GUESSS project, and the assessments of the institutional environment's development are presented in Table 1.

Control variables. Students' personal characteristics (such as gender and age) can significantly affect the emergence of entrepreneurial intentions and, as a consequence, their willingness to take relevant action [Haus et al., 2013; Levesque, Minniti, 2006]; accordingly, these variables were included in the model as control variables. The variable "Age" was measured in years; the missing values were replaced with the averages in accordance with the approach proposed in [Afifi, Elashoff, 1966]. The variable "Gender" is a binary variable: it takes the value of 1 for female and 0 for male students. In addition to socio-demographic characteristics, students' major specialization was also taken into account [Kolverei, Moen, 1997] given that students studying economics or business/management can be expected to be more inclined towards entrepreneurship. This variable is also binary, and takes the value of 1 if the student specializes in the above fields, and 0 in all other cases.

We tested the reliability of latent variables' values in the model. Cronbach's alpha for entrepreneurial intentions was 0.95 , and for university entrepreneurial environment it was 0.88 , which is above the recommended value of 0.7 and therefore indicates the inherent compliance of the characteristic chosen to describe the above theoretical constructs [Cronbach, 1951]. Descriptive statistics for the variables and the correlation matrix are presented in Tables 2 and 3.

\section{Data analysis results}

The study's hypotheses were tested by evaluating a three-step logistic regression. To exclude heteroscedasticity, robust standard errors were used at all three stages of the evaluation. The results of testing the hypotheses are presented in Table 4. 


\section{Table 1. Assessment of Russian regional institutional environments' development (2014)}

\begin{tabular}{|c|c|c|c|c|c|c|c|}
\hline Регион & $\begin{array}{l}\text { Number of } \\
\text { respondents }\end{array}$ & $\begin{array}{l}\text { Production } \\
\text { factors }\end{array}$ & $\begin{array}{l}\text { Demand and } \\
\text { competition }\end{array}$ & $\begin{array}{c}\text { Regulatory } \\
\text { impact }\end{array}$ & $\begin{array}{l}\text { Macroeconomic } \\
\text { risks }\end{array}$ & $\begin{array}{c}\text { Administrative } \\
\text { barriers and } \\
\text { corruption }\end{array}$ & Total \\
\hline Altai Republic & 38 & 3 & 1 & 2 & 1 & 2 & 9 \\
\hline Astrakhan Region & 55 & 1 & 1 & 1 & 3 & 2 & 8 \\
\hline Bryansk Region & 123 & 1 & 2 & 2 & 1 & 2 & 8 \\
\hline Volgograd Region & 101 & 1 & 2 & 2 & 2 & 1 & 8 \\
\hline Voronezh Region & 90 & 2 & 2 & 2 & 2 & 3 & 11 \\
\hline Irkutsk Region & 142 & 1 & 2 & 2 & 3 & 3 & 11 \\
\hline Krasnoyarsk Region & 90 & 2 & 2 & 1 & 1 & 2 & 8 \\
\hline Moscow & 540 & 2 & 3 & 3 & 2 & 2 & 12 \\
\hline Novgorod Region & 211 & 2 & 2 & 2 & 3 & 2 & 11 \\
\hline Novosibirsk Region & 82 & 2 & 2 & 2 & 3 & 2 & 11 \\
\hline Perm Region & 225 & 1 & 3 & 3 & 2 & 1 & 10 \\
\hline Primorsky Region & 186 & 2 & 1 & 1 & 2 & 3 & 9 \\
\hline $\begin{array}{l}\text { Republic of Sakha } \\
\text { (Yakutia) }\end{array}$ & 222 & 3 & 2 & 3 & 3 & 3 & 14 \\
\hline Republic of Tatarstan & 469 & 2 & 3 & 3 & 3 & 3 & 14 \\
\hline Rostov Region & 83 & 1 & 2 & 3 & 3 & 3 & 12 \\
\hline St. Petersburg & 1026 & 2 & 3 & 2 & 3 & 3 & 13 \\
\hline Sverdlovsk Region & 42 & 1 & 3 & 2 & 2 & 2 & 10 \\
\hline Stavropol Region & 635 & 1 & 2 & 1 & 2 & 2 & 8 \\
\hline Tomsk Region & 97 & 2 & 3 & 2 & 2 & 2 & 11 \\
\hline
\end{tabular}

At the first stage of the study, the control variables' effects were measured (Model 1), and a positive correlation was discovered between students' age $(\mathrm{b}=0.038, \mathrm{p}<0.05)$ and actual steps taken to start their own business. It was established that women were less likely than men to realize their entrepreneurial intentions $(b=-0.981, p<0.001)$. Finally, students specializing in economics or business management demonstrated a more pronounced inclination to implement their business ideas compared with all others $(\mathrm{b}=0.487, \mathrm{p}<0.001)$.

At the second stage, the main effects were added to the model (Model 2) and a direct relationship was found between students' intentions and participation in entrepreneurial activities $(b=0.503, p<0.001)$. Also, the positive effect of a family entrepreneurial background was established $(b=0.418, p<0.001)$, as was the negative influence of the university entrepreneurial environment $(b=-0.057, p<0.05)$.

At the third stage, the testing of moderation effects (Model 3), after adding the moderators, the assessment of the regression coefficient "Entrepreneurial intentions" variable ceased to be statistically significant, which implies that the nature of transition from entrepreneurial intentions to action is situational. The results of empirical testing revealed that one of the factors promoting this process was the level of the development of the regional institutional environment $(b=0.042, p<0.05)$, which confirms hypothesis $\mathrm{H} 3$. The coefficient of the variable reflecting students' family entrepreneurial background turned out to be negative, i.e., students whose parents are entrepreneurs are less likely to implement their own business initiatives $(b=-0.102, p<0.1)$, which refutes hypothesis $\mathrm{H} 1$. The regression coefficient of university

Table 2. Descriptive statistics

\begin{tabular}{|c|c|c|c|c|}
\hline Variable & Mean value & Standard deviation & Min & Max \\
\hline 1. Involvement in start-up activities & - & - & 0 & 1 \\
\hline 2. Entrepreneurial intentions & 4.60 & 1.62 & 1 & 7 \\
\hline 3. Family entrepreneurial background & - & - & 0 & 1 \\
\hline 4. University entrepreneurial environment & 4.43 & 1.57 & 1 & 7 \\
\hline 5. Regional institutions & 9.54 & 1.78 & 6 & 12 \\
\hline 6. Age & 20.14 & 1.86 & 17 & 40 \\
\hline 7. Gender & - & - & 0 & 1 \\
\hline 8. Specialization & - & - & 0 & 1 \\
\hline
\end{tabular}


Table 3. Correlation matrix

\begin{tabular}{|c|c|c|c|c|c|c|c|c|}
\hline Variables & 1 & 2 & 3 & 4 & 5 & 6 & 7 & 8 \\
\hline 1. Involvement in start-up activities & 1 & & & & & & & \\
\hline 2. Entrepreneurial intentions & $0.254^{\star *}$ & 1 & & & & & & \\
\hline 3. Family entrepreneurial background & $0.010^{* *}$ & $0.099^{* *}$ & 1 & & & & & \\
\hline 4. University entrepreneurial environment & $0.031^{*}$ & 0.266 & -0.004 & 1 & & & & \\
\hline 5. Regional institutions & -0.005 & $-0.067^{\star *}$ & -0.015 & $-0.031^{*}$ & 1 & & & \\
\hline 6. Age & $0.041^{*}$ & -0.001 & $-0.039^{*}$ & $-0.033^{\star}$ & $-0.031^{\star}$ & 1 & & \\
\hline 7. Gender & $-0.188^{\star *}$ & -0.028 & $-0.028 \dagger$ & 0.019 & $-0.048^{*}$ & $-0.052^{\star *}$ & 1 & \\
\hline 8. Specialization & $0.089^{* *}$ & $0.064^{\star *}$ & $0.064^{\star *}$ & $0.094^{* *}$ & $0.065^{\star *}$ & $0.038^{*}$ & 0.002 & 1 \\
\hline \multicolumn{9}{|c|}{$\begin{array}{l}\dagger \mathrm{p}<0.1 ;{ }^{*} \mathrm{p}<0.05 ;{ }^{* *} \mathrm{p}<0.001 \text { ( } 2 \text {-tailed). } \\
\text { Note: A point biserial correlation coefficient was used to calculate the correlation between variables if one of them was binary; in all other cases, the Pearson } \\
\text { correlation coefficient was used. } \\
\text { Source: compiled by the authors. }\end{array}$} \\
\hline
\end{tabular}

entrepreneurial environment turned out to be insignificant, which means that hypothesis $\mathrm{H} 2$ was not confirmed.

\section{Discussion}

The theory of planned behavior [Ajzen, 1991] implies a direct relationship between intentions and the actions taken to implement them. The results of our study confirmed the validity of this theory regarding the transition from entrepreneurial aspirations to starting and running one's own business by early-stage entrepreneurs - the students of Russian universities. This intuitively reliable conclusion corresponds with most of the relevant studies [Kautonen et al., 2013, 2015; Liñán, Fayolle, 2015; Shirokova et al., 2015; van Gelderen et al., 2015]. At the same time, the theory of planned behavior (which was developed primarily to explain the mechanism of intention formation) does not fully explain the gap between intentions and action, i.e., the situations where declared intentions were not actually realized. Our results show that the transition from the former to the latter is affected by the context, by factors that can either increase or reduce the probability of such a transition.

Students who are considering a career in entrepreneurship and come from business-owning families are rather less likely to realize such intentions. This finding contradicts our initial hypothesis about the role of family business in this process. There may be several possible explanations. Firstly, people who come

Table 4. Regression analysis results

\begin{tabular}{|c|c|c|c|}
\hline Variables & Model 1 & Model 2 & Model 3 \\
\hline \multicolumn{4}{|c|}{ Control variables } \\
\hline Age & $0.038^{*}$ & $0.064^{\star *}$ & $0.062^{\star *}$ \\
\hline Gender & $-0.981^{\star * \star}$ & $-0.954^{\star * \star}$ & $-0.956^{\star * \star}$ \\
\hline Specialization & $0.487^{\star * *}$ & $0.319^{* * *}$ & $0.312^{\star * *}$ \\
\hline \multicolumn{4}{|c|}{ Main effects } \\
\hline Entrepreneurial intentions & & $0.503^{\star \star \star}$ & 0.201 \\
\hline Family entrepreneurial background & & $0.418^{\star * \star}$ & $0.973^{\star *}$ \\
\hline University entrepreneurial environment & & $-0.057^{\star}$ & 0.031 \\
\hline Regional institutions & & -0.002 & $-0.227^{\star *}$ \\
\hline \multicolumn{4}{|l|}{ Moderating effects } \\
\hline Entrepreneurial intentions X family entrepreneurial background & & & $-0.102 \dagger$ \\
\hline Entrepreneurial intentions X university entrepreneurial environment & & & -0.015 \\
\hline Entrepreneurial intentions X regional institutions & & & $0.042^{\star}$ \\
\hline Constant & $-1.844^{* * *}$ & $-4.681^{* * *}$ & $-3.038^{\star *}$ \\
\hline $\mathrm{N}$ & 4479 & 4358 & 4358 \\
\hline Prob > chi2 & 0.000 & 0.000 & 0.000 \\
\hline Pseudo R2 & 0.045 & 0.119 & 0.121 \\
\hline
\end{tabular}


from business-owning families can realize their entrepreneurial aspirations not just by creating their own firm but also by becoming the successor to the family business. This saves such nascent entrepreneurs from taking numerous steps on their own, which may partially explain the established negative correlation between coming from a business-owning family and taking action to implement one's entrepreneurial intentions. This hypothesis is confirmed by the results of the GUESSS 2013-2014 study: the average measured value of the assessment by Russian students coming from business-owning families about their joining the family firm as a possible career path was higher than that of the international sample: 3.41 vs. 2.67, respectively [Shirokova et al., 2015b]. Another factor likely affecting the lower rate of Russian students coming from business-owning families realizing their entrepreneurial intentions may be doubts concerning the prospects of such a career in Russia, reinforced by the practical experience of their family. Russian businesses, which has to survive in a developing economy, are highly dynamic and highly aggressive [Puffer, McCarthy, 2001]. The negative business experience of family members may prompt students to abandon their entrepreneurial aspirations and pursue a career outside of entrepreneurship.

We were unable to confirm a relationship between a developed entrepreneurial environment at a student's university and the likelihood of he or she making the transition from entrepreneurial aspirations to establishing a business. Despite the obvious success of providing various kinds of support to student entrepreneurship, the overall relevant infrastructure needs further development [Karpunina et al., 2014]. An important step along this path would the adoption of the entrepreneurial university model as a target milestone [Bokov et al., 2011; Ivashchenko et al, 2014]. This model covers various areas of university activity in addition to academic initiatives, and stipulates the creation of innovation centers, the commercialization of research results, the expansion of funding sources, the promotion of an entrepreneurial culture and a good business environment, and active cooperation with members of the business community [Ivashchenko et al., 2014; Konstantinov, Filonovich, 2007; Tappaskhanova et al., 2014]. Implementing such initiatives at Russian universities would provide a significant incentive for transforming students' entrepreneurial aspirations into actual efforts at founding a firm.

Finally, we established a positive moderating effect from the level of development of the regional entrepreneurial infrastructure on the link between students' entrepreneurial intentions and actions. This is in line with the initial assumption about the effect of the local institutional context on people's business activities. As was shown in a recent study [Aleksandrova, Verkhovskaya, 2015], one of the more important factors of the latter is the positive perception of business conditions in the region. Our conclusions confirm the validity of this thesis regarding the realization of entrepreneurial intentions. Due to significantly differing business conditions across various Russian regions, SMEs are not developing evenly in the country [Gosudarstvennyi Sovet Rossiiskoi Federatsii, 2015]. Of course, the specific regional policies are affected by the nation-wide policies, and by each region's particular development goals and objectives [Gnevko, 2010]. However, as we were able to demonstrate, a regional system for providing various kinds of support to entrepreneurship via programs based on the Federal Law No. 209-FZ "On the development of small and medium entrepreneurship in the Russian Federation" of 24.07.2007, or through indirect measures to promote effective demand, combat corruption, and improve the regional macro-economic situation, could increase the number of young entrepreneurs willing to move from intentions to action, start their own businesses and contribute to an overall increase in business activity.

\section{Contribution to theory and practical significance of this study}

Our study was intended to obtain a deeper understanding of the relationship between the main components of the entrepreneurial process in Russia. It further clarifies the theory of planned behavior [Ajzen, 1991] regarding factors that could presumably affect the transition from intention to entrepreneurial action. We demonstrated the applicability of the "embeddedness" concept [Granovetter, 1985] to various kinds of people's business activities. Finally, we tried to extend the scope of applying the institutional approach to studying entrepreneurship by revealing the role of regional institutions in the conversion of entrepreneurial aspirations into relevant action in the context of emerging markets.

The conclusions made on the basis of this study could be useful to the developers of regional entrepreneurship promotion programs. In particular, we have in mind the variety of factors affecting the entrepreneurial intention-action transition, specifically the unique Russian aspects of this process. The new knowledge can also be applied in business education programs offered at Russian universities, which in the end ultimately affect the level of students' overall entrepreneurial activities.

\section{Limitations and areas for further research}

Cross-sectional data were used in our study, i.e., the strength of entrepreneurial intentions and action taken to create new businesses were measured at just one point in time - providing no opportunity to assess their dynamics. Since intentions tend to change, their explanatory function reduces with time [Sutton, 1998]; therefore, the role of various factors affecting the intention-action transition was in the 
focus of our paper. Still, a possible area for studying the link between intentions and actual entrepreneurial activities in the Russian context might be found in longitudinal studies.

In this paper, we relied on an exclusively student sample, which does not allow us to extrapolate the results for other early-stage entrepreneur groups. Another possible area for future research could be testing the factors affecting the entrepreneurial intention-action transition of members of different social groups. Also, the results of our analysis are relevant only for the Russian context. Similar studies conducted in other countries would probably discover other constellations of entrepreneurial ecosystem elements for consideration.

Finally, we attempted to measure the unidirectional links between the main elements of the business process. However, moving on from entrepreneurial intentions to action is a complex and multifaceted activity, so studying it involves the application of quantitative research techniques to fully understand all its aspects.

\section{Conclusion}

The theory of planned behavior implies a direct relationship between intentions and the steps taken to implement them. In the case of entrepreneurship, this relationship can be strengthened or weakened by a host of context-dependent factors. In our study, we used the embeddedness perspective to establish the negative effect of students' family entrepreneurial background on their transition from having business aspirations to taking relevant action, and the positive effect of the regional institutional entrepreneurial environment on this process. Our paper contributes to advancing entrepreneurship studies, and has practical value for the designers of regional business promotion programs and relevant educational initiatives.

This research was conducted with financial support from a Russian Science Foundation grant (project No. 14-18-01093).

\section{References}

Afifi A.A., Elashoff R.M. (1966) Missing Observations in Multivariate Statistics. Journal of American Statistical Association, no 61 (315), pp. 595-605.

Ajzen I. (1991) The Theory of Planned Behavior. Organizational Behavior \& Human Decision Processes, vol. 50, no 2, pp. 179-211.

Ajzen I., Czasch C., Flood M.G. (2009) From Intentions to Behavior: Implementation Intention, Commitment, and Conscientiousness. Journal of Applied Social Psychology, vol. 39, no 6, pp. 1356-1372.

Aleksandrova E.A., Verkhovskaya O.R. (2015) Predprinimatel'skie namereniya v Rossii: empiricheskii analiz [Entrepreneurial Intentions in Russia: Empirical Analysis]. Rossiiskii zhurnal menedzhmenta [Russian Management Journal], vol.13, no 2, pp. 2-26 (in Russian).

Armitage C.J., Conner M. (2001) Efficacy of the Theory of Planned Behavior: A Meta-Analytic Review. British Journal of Social Psychology, vol. 40, no 4, pp. 471-499.

Bae T.J., Qian S., Miao C., Fiet, J.O. (2014) The Relationship between Entrepreneurship Education and Entrepreneurial Intentions: A Meta-Analytic Review. Entrepreneurship Theory \& Practice, vol. 38, no 2, pp. 217-254.

Bird B.J. (1988) Implementing Entrepreneurial Ideas: The Case for Intention. Academy of Management Review, vol. 13 , no 3, pp. 442-453.

Bokov L.A., Kobzev A.V., Uvarov A.F., Shurygin Yu.A. (2011) Na puti k predprinimatel'skomu universitetu [On the Way to Entrepreneurial University]. Innovatsii [Innovations], no 4, pp. 11-17 (in Russian).

Bruton G.D., Ahlstrom D., Han-Lin L. (2010) Institutional Theory and Entrepreneurship: Where are We Now and Where do We Need to Move in the Future? Entrepreneurship: Theory \& Practice, vol. 34, no 3, pp. 421-440.

Chlosta S., Patzelt H., Klein S.B., Dormann C. (2012) Parental Role Models and the Decision to Become Selfemployed: The Moderating Effect of Personality. Small Business Economics, vol. 38, no 1, pp. 121-138.

Costa L., Mainardes E.W. (2016) The Role of Corruption and Risk Aversion in Entrepreneurial Intentions. Applied Economics Letters, vol. 23, no 4, pp. 290-293.

Cronbach L. (1951) Coefficient Alpha and the Internal Structure of Tests. Psychometrika, no 16, pp. 297-334.

Davidsson P., Honig B. (2003) The Role of Social and Human Capital among Nascent Entrepreneurs. Journal of Business Venturing, vol. 18, no 3, pp. 301-331.

De Clercq D., Arenius P. (2006) The Role of Knowledge in Business Start-Up Activities. International Small Business Journal, vol. 24, no 4, pp. 339-358.

Djankov S., Miguel E., Qian Y., Roland G., Zhuravskaya E. (2006) Entrepreneurship: First Results from Russia (CEPR Discussion Papers 5707), London: CEPR.

Dunn T., Holtz-Eakin D. (2000) Human Capital and the Transition to Self-Employment: Evidence from Intergenerational Links. Journal of Labor Economics, vol. 18, no 2, pp. 282-305.

EBRD (2012) Diversifying Russia, London: European Bank for Reconstruction and Development. Available at: http:// www.ebrd.com/news/publications/special-reports/diversifying-russia.html, accessed 18.02.2016.

Franke N., Lüthje C. (2004) Entrepreneurial Intentions of Business Students: A Benchmarking Study. International Journal of Innovation and Technology Management, vol. 1, no 3, pp. 269-288.

Fritsch M., Storey D.J. (2014) Entrepreneurship in a Regional Context: Historical Roots, Recent Developments and Future Challenges. Regional Studies, vol. 48, no 6, pp. 939-954.

Geissler M. (2013) Determinanten des Vorgründungsprozesses, Wiesbaden: Springer Fachmedien Wiesbaden.

Gnevko V.A. (ed.) (2010) Regional'nye aspekty funktsionirovaniya i razvitiya malogo predprinimatel'stva $v$ Rossii [Regional Aspects of Russian Entrepreneurship Functioning and Development], Saint-Petersburgh.: SaintPetersburgh Academy of Governance and Economy (in Russian). 
Gosudarstvennyi Sovet Rossiiskoi Federatsii (2015) Doklad o merakh po razvitiyu malogo i srednego predprinimatel'stva v Rossiiskoi Federatsii [Report on the Measures of Small and Medium Sized Enterprises Development in the Russian Federation], Moscow: Kremlin. Available at: http://www.smeforum.ru/upload/ iblock/f81/f810c5d73204a810a2889cfc43d6aae9.pdf, accessed 25.01.2016 (in Russian).

Granovetter M. (1985) Economic Action and Social Structure: The Problem of Embeddedness. The American Journal of Sociology, vol. 91, no 3, pp. 481-510.

Haus I., Steinmetz H., Isidor R., Kabst R. (2013) Gender Effects on Entrepreneurial Intention: A Meta-Analytical Structural Equation Model. International Journal of Gender and Entrepreneurship, vol. 5, no 2, pp. 130-156.

Heuer A., Liñán F. (2013) Testing Alternative Measures of Subjective Norms in Entrepreneurial Intention Models. International Journal of Entrepreneurship and Small Business, vol. 19, no 1, pp. 35-50.

Hughes M., Ireland R.D., Morgan R.E. (2007) Stimulating Dynamic Value: Social Capital and Business Incubation as a Pathway to Competitive Success. Long Range Planning, vol. 40, no 2, pp. 154-177.

Ivashchenko N.P., Engovatova A.A., Korostyleva I.I. (2014) Transformatsiya otechestvennykh vuzov v predprinimatel'skie: logika puti [Transformation of Domestic Universities into Entrepreneurial Ones: Logic of the Route]. Ekonomicheskie strategii, vol. 16, no 8 (124), pp. 130-135 (in Russian).

Karpunina M.A., Savinova S.Yu., Shubnyakova N.G. (2014) Formirovanie molodezhnogo predprinimatel'skogo soobshchestva kak instrument povysheniya predprinimatel'skoi aktivnosti v Possii [Formation of Youth Entrepreneurial Community as an Instrument for Development of Entrepreneurial Activity in Russia]. Sovremennye problemy nauki i obrazovaniya (electronic journal), vol. 2. Available at: http://science-education.ru/ $\mathrm{ru} /$ article/view?id=12360, accessed 15.02.2016 (in Russian).

Kautonen T., van Gelderen M., Fink M. (2015). Robustness of the Theory of Planned Behavior in Predicting Entrepreneurial Intentions and Actions. Entrepreneurship: Theory and Practice, vol. 39, no 3, pp. 655-674.

Kautonen T., van Gelderen M., Tornikoski E.T. (2013) Predicting Entrepreneurial Behavior: A Test of the Theory of Planned Behavior. Applied Economics, vol. 45, no 6, pp. 697-707.

Khairetdinova O.A. (2014) Znachenie studencheskogo predprinimatel'stva na sovremennom etape razvitiya Rossii [Importance of Student Entrepreneurship at the Contemporary Stage of Russia's Development]. Science Time, no 5 (5), pp. 225-233 (in Russian).

Kibler E. (2013) Formation of Entrepreneurial Intentions in a Regional Context. Entrepreneurship and Regional Development: An International Journal, vol. 25, no 3-4, pp. 292-323.

Klofsten M. (2000) Training Entrepreneurship at Universities: A Swedish Case. Journal of European Industrial Training, vol. 24, no 6, pp. 337-344.

Kolverei L., Moen O. (1997) Entrepreneurship among Business Graduates: Does a Major in Entrepreneurship Make a Difference? Journal of European Industrial Training, vol. 21, no 4/5, pp. 154-160.

Konstantinov G.N., Filonovich S.R. (2007) Chto takoe predprinimatel'skii universitet [What is a business-oriented university?], Voprosy obrazovania / Educational Studies Moscow, no 1, pp. 49-62 (in Russian).

Konyukhova E. (2014) Predprinimatel'skie kompetentsii kak garantii kachestva programm po obucheniyu predprinimatel'stvu [Entrepreneurial Competences as a Guarantee of the Entrepreneurial Education Quality]. Kachestvo obrazovaniya, no 12, pp. 48-52 (in Russian).

Krueger N.F. (2009) Entrepreneurial Intentions are Dead: Long Live Entrepreneurial Intentions. Understanding the entrepreneurial mind, international studies in entrepreneurship (eds. A.L. Carsrud, M. Brännback), New York: Springer, pp. 51-72.

Kutsenko E. (2015) Pilotnye innovatsionnye territorial'nye klastery Rossii: model' ustoichivogo razvitiya [Pilot Innovative Regional Clusters in Russia: Model for a Sustainable Development], Foresight and STI Governance, vol. 9, no 1, pp. 32-55 (in Russian).

Laspita S., Breugst N., Heblich S., Patzelt H. (2012) Intergenerational Transmission of Entrepreneurial Intentions. Journal of Business Venturing, vol. 27, no 4, pp. 414-435.

Lentz B.F., Laband D.N. (1990) Entrepreneurial Success and Occupational Inheritance among Proprietors. Canadian Journal of Economics, vol. 23, no 3, pp. 563-579.

Lévesque M., Minniti M. (2011) Age Matters: How Demographics Influence Aggregate Entrepreneurship. Strategic Entrepreneurship Journal, vol. 5, no 3, pp. 269-284.

Liñán F. Fayolle A. (2015) A Systematic Literature Review on Entrepreneurial Intentions: Citation, Thematic Analyses, and Research Agenda. International Entrepreneurship and Management Journal, vol. 11, no 4, pp. 907-933.

Liñán F., Chen Y.W. (2009) Development and Cross-Cultural Application of a Specific Instrument to Measure Entrepreneurial Intentions. Entrepreneurship: Theory \& Practice, vol. 33, no 3, pp. 593-617.

Liñán F., Rodriguez-Cohard J.C. (2015) Assessing the Stability of Graduates' Entrepreneurial Intention and Exploring its Predictive Capacity. Academia Revista Latinoamericana de Administración, vol. 8, no 1, pp. 77-98.

Makarov S., Ugnich E. (2015) Biznes-katalizatory kak draivery razvitiya regional'nykh innovatsionnykh sistem [Business Catalyzers as Drivers of Regional Innovation Systems Developmet]. Foresight-Russia, vol. 9, no 1, pp. 56-67 (in Russian).

McCarthy D., Puffer S., Darda S. V. (2010) Convergence in Entrepreneurial Leadership Style: Evidence from Russia. California Management Review, vol. 52, no 4, pp. 48-72.

Morales-Gualdron S.T., Roig S. (2005) The New Venture Decision: An Analysis Based on the GEM Project Database. International Entrepreneurship and Management Journal, vol. 1, no 4, pp. 479-499.

MSP Bank (2014) Index kachestva uslovii dlya malogo I srednego biznesa v 2012-2013 gg.: regional'nye disproportsii [Quality Index for SMEs in 2012-2013], Moscow: MSP Bank Analytical Center. Available at: https://www.mspbank. ru/userfiles/files/researches/index_kach_2012-2013_reg.pdf, accessed 21.04.2017 (in Russian).

Mueller P. (2006) Entrepreneurship in the Region: Breeding Ground for Nascent Entrepreneurs? Small Business Economics, vol. 27, no 1, pp. 41-58.

Nielsen S.L., Lassen A.H. (2012) Identity in Entrepreneurship Effectuation Theory: A Supplementary Framework. International Entrepreneurship and Management Journal, vol. 8, no 3, pp. 373-389.

Orbell S., Sheeran P. (1998) Inclined Abstainers': A Problem for Predicting Health-Related Behavior. British Journal of Social Psychology, vol. 37, no 2, pp. 151-165.

Parker S.C., Belghitar Y. (2006) What Happens to Nascent Entrepreneurs? An Econometric Analysis of the PSED. Small Business Economics, vol. 27, no 1, pp. 81-101.

Pavlov K.V. (2008) Regional'nye osobennosti razvitiya rossiiskogo predprinimatel'stva [Regional Peculiarities of Russian Entrepreneurship Development], Vestnik MGTU, vol. 11, no 2, pp. 254-263 (in Russian).

Peng M. (2003) Institutional Transitions and Strategic Choices. Academy of Management Review, vol. 28, no 1, pp. 275-296.

Puffer S.M., McCarthy D.J. (2001) Navigating the Hostile Maze: A Framework for Russian Entrepreneurship. Academy of Management Executive, vol. 15, no 3, pp. 24-36. 
Rauch A. (2014). Predictions of Entrepreneurial Behavior: A Personality Approach. Handbook of Research on Small Business and Entrepreneurship (eds. E. Chell, M. Karataş-Özkan), Cheltenham: Edward Elgar, pp. 165-183.

Reznik G.A., Ponomarenko Y.S. (2010) Studencheskoe predprinimatel'stvo kak vazhnyi faktor formirovaniya innovatsionnoi ekonomiki [Student Entrepreneurship as an Important Factor of Innovative Economy Formation]. Universitetskoe upravlenie: praktika i analiz, no 2, pp. 62-67 (in Russian).

Romanovskaya A. (2015) Bol'shie problemy malogo biznesa [Big Problems of Small Business]. Valovyi vnutrennii produkt (electronic journal), no 5(94). Available at: http://www.vvprf.ru/archive/clause1107.html, accessed 27.01.2016 (in Russian)

Saidullaev F.S. (2015) Dinamika razvitiya malogo predprinimatel'stva v regionakh Rossii v 2014 godu. Ezhekvartal'nyi informatsionno-analiticheskii otchet [Dynamics of Small-scale Entrepreneurship development in Russian Regions in 2014. Quarterly Analytical Report], Moscow: Natsional'nyi institut sistemnykh issledovanii problem predprinimatel'stva [National Institute for Entrepreneurship Research]. Available at: http://nisse.ru/upload/ iblock/01e/4\%20kvartal_2014.pdf, accessed 28.01.2016 (in Russian).

Schlaegel C., Koenig M. (2014) Determinants of Entrepreneurial Intent: A Meta Analytic Test and Integration of Competing Models. Entrepreneurship: Theory and Practice, vol. 38, no 2, pp. 291-332.

Sequeira S., Mueller S., McGee J. (2007) The Influence of Social Ties and Self-Efficacy In Forming Entrepreneurial Intentions and Motivating Nascent Behavior. Journal of Developmental Entrepreneurship, vol. 12, no 3, pp. 275-293.

Shapero A., Sokol L. (1982) Social dimensions of entrepreneurship. The Encyclopedia of Entrepreneurship (eds. C. Kent, D. Sexton, K. Vesper), Englewood Cliffs, NJ: Prentice-Hall, pp. 72-90.

Shchegolev V.V., Nikolaev N.A. (2014) Izuchenie i podderzhka predprinimatel'skikh namerenii studentov [Studying and Supporting Students' Entrepreneurial Intentions]. Sovremennye problemy nauki i obrazovaniya [Modern problems of science and education] (electronic journal), no 6. Available at: http://science-education.ru/ru/article/ view?id=16745, accessed 21.04.2016 (in Russian).

Shcherbakova E.A. (2012) Innovatsionnyi podkhod k obucheniyu predprinimatel'stvu [Innovative Approach towards Entrepreneurship Education]. Vestnik Yuzhno-Rossiiskogo gosudarstvennogo tekhnicheskogo universiteta (Novocherkasskogo politekhnicheskogo instituta). Seriya: Sotsialno-ekonomicheskie nauki, no 3, pp. 83-86 (in Russian).

Sheeran P. (2002) Intentions-Behavior Relations: A Conceptual and Empirical Review. European Review of Social Psychology, vol. 12, pp. 1-36.

Shirokova G., Osiyevskyy O., Bogatyreva K. (2016) Exploring the Intention-Behavior Link in Student Entrepreneurship: Moderating Effects of Individual and Environmental Characteristics. European Management Journal, vol. 34, no 4, pp. 386-399.

Shirokova G., Tsukanova T., Bogatyreva K. (2015a) Faktory formirovaniya predprinimatel'skikh namerenii rossiiskikh studentov [Antecedents of students's entrepreneurial intentions in Russia]. Vestnik Sankt-Peterburgskogo universitetata. Seriya Menedzhment [Vestnik of Saint Petersburg University. Management Series], no 3, pp. 21-46 (in Russian).

Shirokova G., Tsukanova T., Bogatyreva K. (2015b) Universitetskaya sreda i predprinimatel'skaya aktivnost' studentov: rol' biznes-opyta i predprinimatel'skoi samoeffektivnosti [University Environment and Student Entrepreneurship: The Role of Business Experience and Entrepreneurial Self-Efficacy]. Voprosy obrazovania / Educational Studies Moscow, no 3, pp. 171-207 (in Russian).

Shirokova G.V., Bogatyreva K.A., Galkina T.A. (2014) Effektuatsiya i kauzatsiya: vzaimosvyaz' mezhdu universitetskoi infrastrukturoi $\mathrm{i}$ vyborom tipa povedeniya $\mathrm{v}$ protsesse sozdaniya biznesa studentami-predprinimatelyami [Effectuation and Causation: Relationship Between University Infrastructure and Behavioral Choice in New Venture Creation by Student-Entrepreneurs], Rossiiskii zhurnal menedzhmenta [Russian Management Journal], vol. 12, no 3, pp. 59-86 (in Russian).

Shook C.L., Bratianu C. (2010) Entrepreneurial Intent in a Transitional Economy: An Application of the Theory of Planned Behavior to Romanian Students. International Entrepreneurship and Management Journal, vol. 6, no 3, pp. 231-247.

Sniehotta F.F., Schwarzer R., Scholz U., Schüz B. (2005) Action Planning and Coping Planning for Long-Term Lifestyle Change: Theory and Assessment. European Journal of Social Psychology, vol. 35, vol. 4, pp. 565-576.

Stenholm P., Acs Z.J., Wuebker R. (2013) Exploring Country-Level Institutional Arrangements on the Rate and Type of Entrepreneurial Activity. Journal Business Venturing, vol. 28, no 1, pp. 176-193.

Sutton S. (1998) Predicting and Explaining Intentions and Behavior: How Well are We Doing? Journal of Applied Social Psychology, vol. 28, no 15, pp. 1317-1338.

Tappaskhanova E.O., Batova B.Z., Zumakulova Z.A. (2014) Realizatsiya kontseptsii «predprinimatel'skogo universiteta» v regione: Ekonomiko-pravovoi aspekt [Realization of the "Entrepreneurial University" Concept in the Region: Economics and Law Perspective]. Ekonomika i predprinimatel'stvo [Journal of Economy and Entrepreneurship], no 4-2 (45-2), pp. 949-952 (in Russian).

Transparency International (2015) Corruption Perceptions Index 2015. Available at: https://www.transparency.org/ cpi2015, accessed 29.01.2016.

Van Gelderen M., Kautonen T., Fink M. (2015) From Entrepreneurial Intentions to Actions: Self-Control and ActionRelated Doubt, Fear, and Aversion. Journal of Business Venturing, vol. 30, no 5, pp. 655-673.

World Bank (2015) Doklad ob ekonomike Rossii [Russia Economic Report] (World Bank Report no 33). Available at: http://www.worldbank.org/content/dam/Worldbank/document/eca/russia/rer33-rus.pdf, accessed 25.01.2016 (in Russian).

Welter F. (2011) Contextualizing Entrepreneurship - Conceptual Challenges and Ways Forward. Entrepreneurship Theory and Practice, vol. 35, no 1, pp. 65-184.

Welter F., Smallbone D. (2011) Institutional Perspectives on Entrepreneurial Behavior in Challenging Environments. Journal of Small Business Management, vol. 49, no 1, pp. 107-125.

Zakharova A.A. (2013) Problemy razvitiya predprinimatel'skoi aktivnosti studentov v sovremennykh usloviyakh [Current Issues of Student Entrepreneurial Activity Development]. Innovatsii v sovremennoi nauke. Materialy II Mezhdunarodnogo osennego simpoziuma [Innovations in Contemporary Science. Materials of the $2^{\text {nd }}$ International Autumn Simposium] (ed. G.F. Grebenshchikov), Moscow, pp. 139-142 (in Russian).

Zanakis S.H., Renko M., Bullough A. (2012) Nascent Entrepreneurs and the Transition to Entrepreneurship: Why Do People Start New Businesses? Journal of Developmental Entrepreneurship, vol. 17, no 1, pp. 1-25.

Zhang Y., Duysters G., Cloodt M. (2014) The Role of Entrepreneurship Education as a Predictor of University Students' Entrepreneurial Intention. International Entrepreneurship and Management Journal, vol. 10, no 3, pp. 623-641.

Zhao H., Seibert S., Hills G. (2005) The Mediating Role of Self-Efficacy in the Development of Entrepreneurial Intentions. Journal of Applied Psychology, vol. 90, no 6, pp. 1265-1272. 